\title{
Evaluation of Antioxidant, Immunomodulatory and Anticancer Properties of Methanolic Extract of Neolamarckia cadamba Linn. Fruits
}

\author{
Amrita Chatterjee, Neelima Sharma*, Papiya Mitra Mazumder \\ Department of Pharmaceutical Sciences and Technology, Birla Institute of Technology, Mesra, Ranchi, Jharkhand, INDIA.
}

\begin{abstract}
Background: The immune system plays an important role in various diseased conditions. Patients with compromised immune function are at increased risk of exposure. Thus, the evaluation of immunomodulatory activity of plant extracts may be helpful for prophylactic treatment approach. Objectives: The aim of present study is to evaluate the effect of methanolic extract of Neolamarckia cadamba Linn. fruits for antioxidant, immunomodulatory and anticancer properties using in-vitro and in-vitro models. Methods: In the present investigation, antioxidant property of methanolic extract of Neolamarckia cadamba fruits (NCM) was evaluated by superoxide radical and DPPH scavenging activity. The immunomodulatory property of NCM extract was analysed by determining cytokines release (IL-2 and TNF $\alpha$ ) in murine primary thymocytes. The effects of NCM extract on humoral and cellular immunity was analysed under in vivo conditions. The anticancer activity of the extract was evaluated on Jurkat J6 cell line by MTT assay. Results: The methanolic extract of Neolamarckia cadamba fruits showed superoxide and DPPH free radical scavenging antioxidant activity and significantly increased the cytokines release (IL-2 and TNF $\alpha$ ) in murine primary thymocytes. The increased hemagglutination antibody titre and neutrophil adhesion as well as the restoration of cyclophosphamideinduced myelosuppression and DTH response confirm the stimulatory effect of NCM on T cells. In-vitro results on Jurkat $\mathrm{J} 6$ cell line showed the significant increase in cell death confirming its anticancer activity. Conclusion: Thus, it can be concluded that the methanolic extract of the fruits of Neolamarckia cadamba possesses antioxidant activity, immunomodulatory property as well as anticancer potential, suggesting its therapeutic efficiency in the treatment of immune disorders as well as cancer.
\end{abstract}

Key words: Neolamarckia cadamba, Immunomodulatory, Antioxidative, Anticancer, Cytokines, Neutrophil adhesion.

\section{INTRODUCTION}

The immune system plays an important role in various diseased conditions including cancer. Cancer is an uncontrolled proliferation of normal cells due to genetic instabilities including mutation in DNA repair genes or activation of tumour suppressor genes during growth metabolism. The alterations within cells and tissues transform the normal cells into malignant cells. ${ }^{1}$ Cancer as well as its treatments may weaken the immune system. Studies have shown that patients with compromised or suppressed immune function are at increased risk of developing cancer.
The modulation of immune response by either its stimulation or suppression can be a helpful therapy to maintain a diseasefree state. Immunomodulatory agents can provide supportive therapy to the chemotherapy. Natural product resources provide excellent raw material for the discovery and development of novel immunomodulatory compounds. Many studies have been performed to assess the potential utility of natural products as immunomodulatory agents to enhance host responses to disease or infection. ${ }^{2}$ Thus, there is a need to determine the immunomodulatory activity of
Submission Date: 21-07-2020; Revision Date: 15-12-2020; Accepted Date: 14-04-2021

DOI: 10.5530/ijper.55.2s.121 Correspondence:

Dr. Neelima Sharma Department of Pharmaceutical Sciences and Technology, Birla Institute of Technology, Mesra, Ranchi-835215, Jharkhand, INDIA.

Phone no: +91-2275444 Email id: nsharmabit@gmail. com

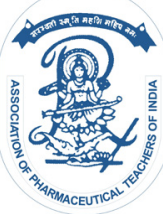

www.ijper.org 
plant extracts as these natural products may be helpful for prophylactic treatment approach.

Neolamarckia cadamba Linn. (Kadam tree) of Rubiaceae family, cultivated in temperate Himalayas, Garhwal, Himachal Pradesh, Sikkim, Assam and Manipur in India, is an important medicinal plant. The tree has a broad crown, straight cylindrical bole and red to orange flowers having sweet fragrance. Its fruits are small in size, close package of fleshy capsules which form a fleshy yelloworange colour containing 8000 seeds. On maturation, fruits split apart and release seeds. ${ }^{3}$ The preliminary phytochemical screening of methanolic extract of the fruits showed the presence of alkaloids, anthraquinone glycoside, flavonoids, phenols, tannins and terpenoids and sterol. In literature, it is reported that methanol and hexane extract of N. cadamba Linn. fruit contains indole alkaloids, secoiridoids, triterpene and proanthocyanidins and anthocyanin. It also contains cadambagenic acid, quinovic acid, $\beta$ - sitosterol, cadambine, cadamine.,

The ethnomedicinal uses and nutritive value of $N$. cadamba was reviewed and described by various researchers. ${ }^{3,4}$ The phytochemical composition and antioxidant property have been reported in the methanolic extracts of leaves and fruits of N. cadamba (Roxb.). ${ }^{5}$ Chandel et al. (2017) identified the active phytoconstituents in its bark and reported antioxidant, antigenotoxic and cytotoxic activity. ${ }^{5}$ The immunomodulatory and anticancer activities have been reported in the extract of $N$. cadamba leaves against cervical cancer. ${ }^{6,7}$ The literature reports reveal that $N$. cadamba fruit possess antioxidant, anthelmintic, membrane stabilizing and antidiabetic properties. ${ }^{8,9}$

As Neolamarckia cadamba plant is of great ethnomedicinal importance, still no scientific report is available regarding the immunomodulatory and anticancer activity of the fruits. The phytochemical screening of leaves and fruits of the plant has shown quite similar constituents. So, it can be assumed that fruits of $N$. cadamba has the potential for immunomodulation and therapeutic efficacy for cancer complications. Thus, the systemic studies to investigate immunomodulatory and anticancer activity in the fruits are warranted. Therefore, the aim of the present investigation is to determine antioxidant, immunomodulatory and anticancer activity in the methanolic extract of $N$. cadamba fruits under in-vitro and in-vivo conditions.

\section{MATERIALS AND METHODS}

\section{Extract preparation}

The fruits of N. cadamba were collected from the garden of B.I.T Mesra, Ranchi, Jharkhand in the month of JulyAugust 2018. The plant was authenticated in Acharya
Jagadish Chandra Bose Indian Botanic Garden (voucher Specimen no. is AC-01/No. /CNH/Tech. II/2019/2). The fruits were shade dried, powdered and subjected to subsequent extraction using $550 \mathrm{gm}$. of dried powder in $2500 \mathrm{ml}$ of $80 \%$ methanol with sporadic shaking. After 15 days, solvent was decanted and filtered with filter paper. To obtain dry product, evaporation of the solvent was done by vacuum rotary evaporator. The percentage yield of the extract was determined. The dry extract was stored at $4^{\circ} \mathrm{C}$ until the experiments were carried out.

\section{Preliminary phytochemical screening and quantitative analysis}

The methanolic extract of $N$. cadamba fruits (NCM) was first of all screened for the preliminary detection of various phytochemical constituents such as alkaloids, flavonoids, carbohydrates, phenols, tannins and glycosides etc. using standard phytochemical screening protocols. ${ }^{10}$ Further, the quantitative analysis of major phytoconstituents such as total phenolic content and total flavonoid content in NCM extract was carried out. ${ }^{11}$

For the determination of total phenolic content, Folinciocalteu method was used. In Brief, $0.5 \mathrm{ml}$ of NCM extract of different concentrations (200, 400, 600, 800, $1000 \mu \mathrm{g} / \mathrm{ml}$ ) was mixed with $1.25 \mathrm{ml}$ of Folin-ciocalteu reagent. Further, $5 \mathrm{ml}$ of sodium carbonate $(7.5 \%)$ was added, mixed and left for $60 \mathrm{~min}$. Absorbance of the solution was read at $765 \mathrm{~nm}$. Simultaneously, Gallic acid standard curve was prepared for determination of the total phenolic content and expressed as, mg Gallic acid equivalent /gm. Total content was determined by

$$
c=\frac{c X v}{x t}
$$

[Where, $\mathrm{C}=$ Total content $\mathrm{mg} / \mathrm{gm}, \mathrm{c}=$ Concentration of Gallic acid established from the calibration curve, $\mathrm{v}=$ volume of extract in $\mathrm{ml}, \mathrm{m}=$ weight of pure plant extract in gm].

The amount of flavonoids in NCM extract was determined by Aluminium chloride reagent method. In Brief, $1 \mathrm{ml}$ of NCM extract of different concentrations (200, $400,600,800,1000 \mu \mathrm{g} / \mathrm{ml}$ ) was mixed with $200 \mu \mathrm{l}$ of $5 \%$ aluminium chloride. Further, the volume was made upto $10 \mathrm{ml}$ with methanol and the absorbance was recorded at $420 \mathrm{~nm}$. Simultaneously, quercetin standard curve was prepared and expressed the flavonoids content as milligrams of quercetin equivalent $(\mathrm{QE}) / \mathrm{g}$. Total content was determined by

$$
c=\frac{c X v}{x t}
$$


[Where, $\mathrm{C}=$ Total content $\mathrm{mg} / \mathrm{gm}, \mathrm{c}=$ Concentration of Quercetin established from the calibration curve in $\mathrm{mg} / \mathrm{ml}, \mathrm{v}=$ volume of extract in $\mathrm{ml}, \mathrm{m}=$ weight of pure plant extract in gm]

\section{Antioxidative property}

The antioxidant property of the NCM extract was measured on the basis of 1,1- diphenyl1-2- picrylhydrazyl $(\mathrm{DPPH})$ and superoxide free radical scavenging activity. ${ }^{12}$ Ascorbic acid was used as the standard.

\section{DPPH scavenging activity}

The DPPH solution $(100 \mu \mathrm{l}$ of $0.1 \mathrm{mM} / \mathrm{L})$ prepared in methanol, was mixed with $200 \mu \mathrm{l}$ of plant extract solution of varying concentrations $(10,25,50,75$, $100,150$ and $200 \mu \mathrm{g} / \mathrm{ml})$. L-Ascorbic acid $(100 \mu \mathrm{g} / \mathrm{ml})$ was used as a reference standard and mixture of DPPH and methanol is considered as control. The absorbance was measured at $517 \mathrm{~nm}$ and the $\%$ inhibition was calculated using the formula,

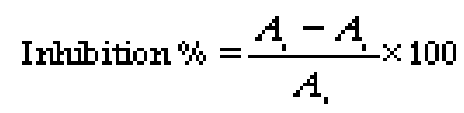

[Where, $A_{c}=$ absorbance of the control, $A_{s}=$ absorbance of the sample]

\section{Superoxide Radical Scavenging Activity}

The assay was based on the capacity of the extract to inhibit formazan formation by scavenging the superoxide radicals generated in riboflavin-light-NBT system. The reaction mixture contained $25 \mathrm{ml}(50 \mathrm{mM})$ phosphate buffer ( $\mathrm{pH}$ 7.6), $(2.2 \mathrm{mg}) 10 \mu \mathrm{l}$ riboflavin, $75 \mu \mathrm{l}$ Triton $\mathrm{X}-100$ and NBT $0.1 \mathrm{mg} / 3 \mathrm{ml}$, added in sequence. The absorbance was measured at $748 \mathrm{~nm}$. The percentage of superoxide anion scavenged was calculated by using the following equation:

$$
\text { Inlubition } \%=\frac{1-A_{1}}{A} \times 100
$$

[Where, $\mathrm{A}_{\mathrm{c}}=$ Absorbance of the Control, $\mathrm{A}_{\mathrm{s}}=$ Absorbance of the Sample]

\section{Immunomodulatory activity}

The immunomodulatory activity of NCM extract was determined under in-vitro conditions by the estimation of cytokines (TNF $\alpha$ and IL-2) in primary thymocytes. All other parameters including haematological parameters, neutrophil adhesion, humoral antibody response to SRBC, delayed-type hypersensitivity response, biochemical estimations and histological analysis were carried out under in-vivo conditions.
Disease free Swiss albino mice weighing (25-30 gm), procured from the animal house of BirlaInstitute of Technology, Mesra, Ranchi, (1968/PO/Re/S/17/CPCSEA) were housed under standard conditions of temperature $(23 \pm 1)^{\circ} \mathrm{C}$ and relative humidity of 45 to $55 \%$ under $12 \mathrm{~h}$ light: $12 \mathrm{~h}$ dark cycle. The mice were fed with standard pellet diet and water ad libitum. All the animals were allowed to acclimatize for two weeks before the commencement of experiments. The experiments were designed and conducted in accordance with guidelines of the committee for the purpose of control and supervision of experiment on animals (CPCSEA) and Institutional animal ethics committee (Approval No. 1972/ $\mathrm{PH} / \mathrm{BIT} / 52 / 18 / \mathrm{IAEC})$.

\section{Cytokines release}

The release of cytokines (IL-2 and TNF $\alpha$ ) was measured in primary thymocytes by using Mouse IL-2, TNF $\alpha$ ELISA kits, respectively. Thymus was dissected from mice and single cell suspension was prepared under aseptic conditions. Briefly, in vitro induction was done by adding $5 \mu \mathrm{g} / \mathrm{ml}$ Con A mitogen per well in $200 \mu \mathrm{l}$ of $1.5 \times 10^{6}$ cells $/ \mathrm{ml}$ in triplicate. NCM extract $(20,50$, 100 and $250 \mu \mathrm{g} / \mathrm{ml}$ ) was added to the wells and incubated at $37^{\circ} \mathrm{C}$ for $48 \mathrm{~h}$ with $5 \% \mathrm{CO}_{2}$. The plate was centrifuged, and the supernatant was used for cytokine estimation. $100 \mu \mathrm{l} /$ well of standards and samples were added into coated well plate and incubated for $1.5 \mathrm{~h}$ at room temperature. The plates were washed and $100 \mu \mathrm{l}$ of detection antibody solution was added to each well and incubated at $37^{\circ} \mathrm{C}$ for $1.5 \mathrm{~h}$. Further, after washing, $100 \mu \mathrm{l}$ of diluted streptavidin-HRP solution was added and incubated at $37^{\circ} \mathrm{C}$ for $30 \mathrm{~min}$. About $100 \mu \mathrm{l}$ of TMB Substrate solution was then added and incubated for 15-30 min in the dark. The reaction was stopped by adding $100 \mu \mathrm{l}$ of stop solution and the resultant absorbance was read at $570 \mathrm{~nm}$ with reference wavelength $690 \mathrm{~nm} .{ }^{13}$

\section{Hemagglutination Antibody Titre test}

The mice were divided into 5 groups containing 6 animals each. Group I received the vehicle and served as control and group II received SRBC $\left(1 \times 10^{8}\right.$ cell i.p.) and treated as SRBC control. Group III was administered the standard drug levamisole (50 mg/ kg, p.o). Group IV and V received NCM extract at the dose of $250 \mathrm{mg} / \mathrm{kg}$ and $500 \mathrm{mg} / \mathrm{kg}$, p.o respectively for 14 days. On $7^{\text {th }}$ day, the mice (Group II- V) were immunized with $0.1 \mathrm{ml}$ of $1 \times 10^{8}$ SRBC. At the end of the experiment, blood was collected from all the animals by retro-orbital puncture and serum was separated. Antibody titres were then determined by serial two-fold dilutions of serum with normal saline in 96-well plate and SRBC $(25 \mu$ l of $1 \%$ 
SRBC prepared in normal saline) added to each of these dilutions. ${ }^{14}$

\section{Cyclophosphamide-induced myelosuppression}

For myelosuppression assay, neutrophil adhesion test and DTH response, the animals were divided into 4 groups containing 6 animals each. Group I received the vehicle and group II received cyclophosphamide (30 mg/kg i.p.). Group III and IV were administered NCM extract daily for 13 days (250 and $500 \mathrm{mg} / \mathrm{kg}$ p.o. respectively). Groups II- IV were injected cyclophosphamide on 11th, 12th and 13th days. Blood samples were collected on $14^{\text {th }}$ day by retro-orbital puncture and haematological parameters were studied such as complete blood cell count, differential count and haemoglobin content. ${ }^{15}$

\section{Neutrophil adhesion test}

The Blood samples collected from all the groups on $14^{\text {th }}$ day, were analysed for total leukocyte count (TLC) and differential leukocyte count (DLC). After the initial counts, the blood samples were incubated with $80 \mathrm{mg} / \mathrm{ml}$ of nylon fibres for $15 \mathrm{~min}$ at $37^{\circ} \mathrm{C}$. Percent neutrophil adhesion was calculated as follows: ${ }^{16}$

$$
\text { Neutrophil adhesion }=\frac{N_{r}-M_{r}}{N I} \times 100
$$

[Where $\mathrm{NI}_{\mathrm{u}}=$ neutrophil index of untreated blood sample, $\mathrm{NI}_{\mathrm{t}}=$ neutrophil index of treated blood sample]

\section{SRBC Induced delayed type of hypersensitivity reaction (DTH response)}

All the groups (I-IV) were primed by subcutaneously injecting SRBC $\left(0.1 \mathrm{ml}, 1 \times 10^{8}\right.$ cells $)$ into the right hind footpad on $7^{\text {th }}$ day. The contra lateral paw also received an equal volume of $0.9 \% \mathrm{NaCl}$, considered as control. The administration of NCM extract and the standard drug were continued till 14th day. On the 14th day, the animals were challenged by subcutaneously injecting $0.1 \mathrm{ml}$ of $1 \times 10^{8}$ SRBCs into the left hind footpad of the mice. The $\%$ change was calculated as follows: ${ }^{17}$

\section{(Left food pad challenged with antigen -}

Right food pa dcortrol) $\times 100$

Left fo ot pa d challenge d with antigen

\section{Biochemical estimations}

The biochemical antioxidant assays were carried out in lymphoid organs (Spleen and Thymus). The levels of malondialdehyde (MDA), reduced glutathione (GSH),
SOD and catalase were estimated in the tissue homogenate of thymus and spleen. ${ }^{18}$

\section{Histopathological analysis}

The fixed specimens of thymus and spleen from control, diseased, standard drug and extract treated groups were processed for dehydration with isopropyl alcohol, clearing and impregnation in paraffin wax. Sections of $4 \mu \mathrm{m}$ thickness were cut using a microtome. The tissue was mounted on the slides with Mayer's albumin solution and after warming it is deparaffinised with xylene. Haematoxylin and eosin staining of the sections was done. The dried and mounted specimens were observed under light microscopy. ${ }^{19}$

\section{Anticancer activity}

The anticancer activity of NCM extract was determined under in-vitro conditions using Jurkat- J6 cell line. Cell population was adjusted to $1.5 \times 10^{6}$ cells $/ \mathrm{ml}$ and $100 \mu \mathrm{l}$ of the cell suspension was added in each well of 96-well plate. Different concentration of NCM extract (20,50, 100,250 and $500 \mu \mathrm{g} / \mathrm{ml}$ ) was added and incubated for $24 \mathrm{~h}$ at $37^{\circ} \mathrm{C}$ with $5 \% \mathrm{CO}_{2} .4 \mathrm{~h}$ prior to the completion of incubation, $10 \mu \mathrm{l}$ MTT $(5 \mathrm{mg} / \mathrm{ml})$ was added in each well. After the incubation, plate was centrifuged, supernatant was discarded, and the resultant Formazan dye was dissolved by adding $100 \mu \mathrm{l}$ DMSO in each well and absorbance taken at $570 \mathrm{~nm}$ in micro-titre plate reader. ${ }^{13}$

\section{Statistical analysis}

The results are expressed as mean \pm standard deviation (SD). Statistical evaluation has been done by using the software Graph pad prism version 5 according to one-way ANOVA.

\section{RESULTS}

\section{Phytochemical screening and quantification of NCM Extract}

The percentage yield of the methanolic fruit extract of N. cadamba was $4.45 \%$ (w/w). Phytochemical screening revealed the presence of alkaloids, anthraquinone glycoside, flavonoids, phenols, tannins and terpenoids and sterol, but saponin showed negative result. Literature reports also confirm the presence of phenolics, flavonoids, proanthocyanidins, and anthocyanin in the fruit methanol extract of the plant. ${ }^{4}$ The levels of the phytoconstituents are generally affected by various factors such as the degree of maturity while harvesting, genetic differences and environmental conditions, etc. Total phenolic and flavonoid content in NCM extract was approximately $302.33 \mathrm{mg}$ GAE (Gallic acid equivalent)/gm and 52.07 $\mathrm{mg}$ (quercetin equivalent)/gm respectively. These results 
are in accordance with reported findings which have shown that $N$. cadamba fruit extract has more phenolic content as compared to leaves. ${ }^{8}$

\section{Antioxidative property of NCM Extract}

The results of DPPH scavenging and superoxide radical scavenging assays revealed the significant antioxidative activity of NCM extract that was comparable to the standard (ascorbic acid). The percentage of free radical inhibition was enhanced with the increase in extract concentration. According to the results of DPPH scavenging activity, the half maximal inhibitory concentration $\left(\mathrm{IC}_{50}\right)$ value of ascorbic acid was $15.95 \mu \mathrm{g} / \mathrm{ml}$ and that of NCM extract was $41.62 \mu \mathrm{g} / \mathrm{ml}$. The antioxidant property of NCM extract is be due to the presence of phenolics content as phenolic compounds have hydroxyl groups which play crucial role in free radical scavenging showing antioxidant property. Literature reports show that both leaf and fruit extracts of the plant exhibit strong DPPH radical-scavenging and $\mathrm{Fe}^{2+}$ chelating activities. However, superoxide anion scavenging activity of the fruit extract is higher than leaf extract. ${ }^{8}$

\section{Immunomodulatory property of NCM Extract Cytokines release}

The results of cytokine estimation in thymocytes showed that levels of both the cytokines (IL-2 and TNF $\alpha$ ) increased significantly in concentration dependent manner in the presence of mitogens, Con A and lipopolysaccharide, respectively. The cells without mitogen induction did not show any significant change. IL-2 level in con $\mathrm{A}$ induced thymocytes increased from $4.6 \pm 0.45$ eg (control) to $9.8 \pm 0.40 \mathrm{gg}(250 \mu \mathrm{g} / \mathrm{ml}$ dose) (Figure $1 \mathrm{~A})$ while TNF $\alpha$ level in lipopolysaccharides induced cells increased from $1.7 \pm 0.15 \mathrm{gg}$ (control) to $4.567 \pm 0.15 \mathrm{gg}$ in the presence of $\mathrm{NCM}$ extract $(250 \mu \mathrm{g} / \mathrm{ml}$ dose $)$ (Figure 1B).

\section{Hemagglutination antibody titre test}

The results of HA titre test suggested that HA unit was significantly greater in standard and treated groups as compared to diseased group. It was due to the increased total leukocyte count in both the groups (Figure 2A). It defines that NCM extract have done hemagglutination with both the concentrations which is the indicative of its immunomodulatory activity (Figure 2B).

\section{Neutrophil adhesion test}

In neutrophil adhesion test, the neutrophil index in nylon fibre treated blood was less than the untreated blood. It was due to the adhesion of neutrophils to the fibres during the incubation of blood with nylon fibres. Further, the neutrophil adhesion in standard and NCM

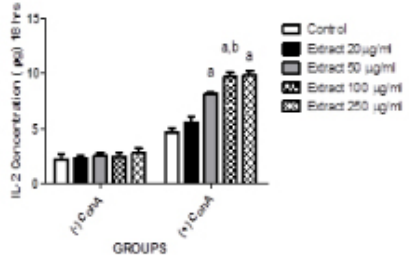

A

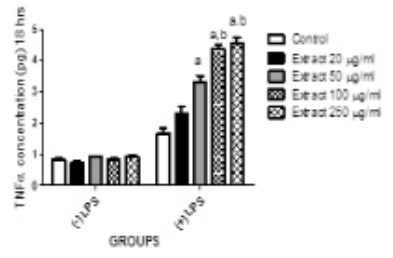

B
Figure 1: Estimation of IL-2 (A) and TNF $\alpha$ (B) in different concentration of samples in thymocytes. The results are shown as Mean \pm SD $(v=3)$ analysed by one -way ANOVA followed by Tukey's multiple comparison test. $\Pi<0.05$ was regarded as statistically significant. a: vs. control, b: vs. $50 \mu \mathrm{g} / \mathrm{ml}$. (-) Con A: in the absence of Con A mitogen, (+) Con A: in the presence of Con A mitogen, (-) LPS: in the absence of Lipopolysaccharide, (+) LPS: in the presence of Lipopolysaccharide.
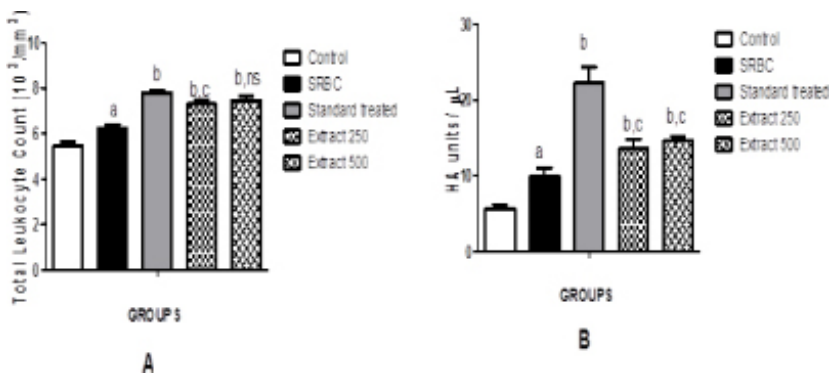

Figure 2: Effect of NCM extract on total leukocyte count (A) and hemagglutination antibody titre (B) in SRBC challenged mice. The results are shown as the Mean \pm SD $(n=6)$ analysed by one -way ANOVA. $P<0.05$ was regarded as statistically significant. a: vs. control, b: vs. SRBC, c: vs. Standard treated, ns is non- significant.

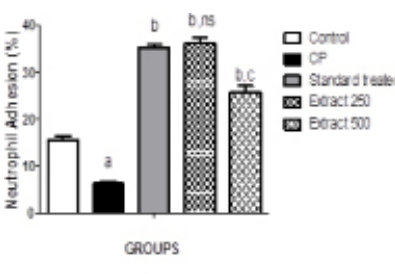

A

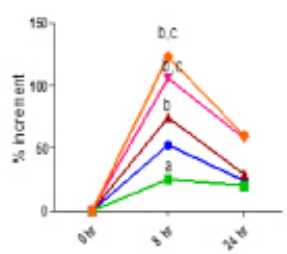

B
Figure 3: Effect of NCM extract on \% neutrophil adhesion (A) and delayed type hypersensitivity reactions in mice by measuring paw size (B). The results are shown as the Mean \pm SD $(n=6)$ analysed by one -way ANOVA. $P<0.05$ was regarded as statistically significant. a: vs. control, b: vs. CP, c: vs. Standard treated, ns is non-significant.

extract treated groups increased than diseased group. NCM extract significantly increased the neutrophil adhesion from $6.69 \%$ (cyclophosphamide treated) to $36.66 \%(250 \mathrm{mg} / \mathrm{kg}$ dose) (Figure 3A).

\section{Effect of NCM extract on Delayed-type hypersensitivity (DTH)}

Delayed type hypersensitivity test is a test for cellular immunity which is determined by the footpad reaction 
Table 1: Complete blood count of cyclophosphamide induced myelosuppressed blood sample.

\begin{tabular}{|c|c|c|c|c|c|}
\hline $\begin{array}{c}\text { Parameters } \\
\text { Groups }\end{array}$ & Control & CP & Standard & $\begin{array}{l}\text { Extract } 250 \\
\mathrm{mg} / \mathrm{kg} \text { bwt }\end{array}$ & Extract $500 \mathrm{mg} / \mathrm{kg} \mathrm{bwt}$ \\
\hline Total leukocyte count $\left(10^{3} / \mathrm{mm}^{3}\right)$ & $5.40 \pm 0.26$ & $2.50 \pm 0.36^{a}$ & $8.67 \pm 0.31^{b}$ & $5.53 \pm 0.12^{b, c}$ & $6.37 \pm 0.25^{\mathrm{b}, \mathrm{c}}$ \\
\hline Total erythrocyte count $\left(10^{6} / \mathrm{mm}^{3}\right)$ & $8.40 \pm 0.20$ & $6.23 \pm 0.15^{a}$ & $8.60 \pm 0.4^{b}$ & $8.47 \pm 0.17^{\mathrm{b}, \mathrm{ns}}$ & $8.50 \pm 0.15^{\mathrm{b}, \mathrm{ns}}$ \\
\hline Platelets $\left(10^{5} / \mathrm{mm}^{3}\right)$ & $629 \pm 1.50$ & $475 \pm 2.08^{a}$ & $787 \pm 0.57^{b}$ & $751 \pm 1.50^{\mathrm{b}, \mathrm{c}}$ & $987 \pm 3.00^{\mathrm{b}, \mathrm{c}}$ \\
\hline \multicolumn{6}{|l|}{ Differential leukocyte count (\%) } \\
\hline Neutrophil & $63.30 \pm 1.50$ & $48.30 \pm 1.50^{\mathrm{a}}$ & $75.00 \pm 1.00^{b}$ & $67.00 \pm 1.00^{\mathrm{b}, \mathrm{c}}$ & $71.30 \pm 1.50^{b, c}$ \\
\hline Lymphocyte & $31.33 \pm 0.57$ & $23.00 \pm 0.57^{a}$ & $39.60 \pm 1.50^{\mathrm{b}}$ & $47 \pm 20.64^{b, c}$ & $43 \pm 0.58^{b, c}$ \\
\hline Eosinophil & $5.30 \pm 0.58$ & $8.67 \pm 1.5^{\mathrm{a}}$ & $2.66 \pm 0.58^{b}$ & $4.66 \pm 0.57^{b, c}$ & $6.00 \pm 1.00^{b, c}$ \\
\hline Monocyte & $1.67 \pm 0.57$ & $0 \pm 0^{\text {ns }}$ & $2.66 \pm 0.57^{b}$ & $3.3 \pm 0.57^{\mathrm{b}, \mathrm{ns}}$ & $2.00 \pm 0.70^{\text {ns,ns }}$ \\
\hline Haemoglobin value (gm./dl) & $13.80 \pm 0.35$ & $11.03 \pm 0.32^{\mathrm{a}}$ & $13.50 \pm 0.30^{b}$ & $13.60 \pm 0.15^{\mathrm{b}, \mathrm{ns}}$ & $11.40 \pm 0.15^{\mathrm{ns}, \mathrm{ns}}$ \\
\hline
\end{tabular}

CP-Cyclophosphamide. The results are shown as the Mean \pm SD $(n=6)$ analysed by one -way ANOVA followed by Tukey's multiple comparison test. $P<0.05$ was regarded as statistically significant. a: vs. control, b: vs. CP, C: vs. Standard treated.

Control-normal control group; CP- cyclophosphamide immunosuppressed group; Standard- immunosuppressed and Levamisole treated (50 mg/kg bwt intra-peritoneal); Extract $250 \mathrm{mg} / \mathrm{kg}$ bwt - immunosuppressed and NCM extract treated ( $250 \mathrm{mg} / \mathrm{kg}$ bwt, intra-peritoneal, daily); Extract $500 \mathrm{mg} / \mathrm{kg}$ bwt - immunosuppressed and NCM extract treated (500 mg/kg bwt, intra-peritoneal, daily).

to SRBC inoculation. The results revealed that NCM extract produced dose-dependent percentage increase in DTH reaction i.e. $60 \%$ with $250 \mathrm{mg} / \mathrm{kg}$ dose and $62 \%$ with $500 \mathrm{mg} / \mathrm{kg}$ dose, as compared to control $(24 \%)$ at $24 \mathrm{~h}$. This confirms the stimulatory effect of NCM extract on T cells (Figure 3B).

\section{Effect of NCM extract on Cyclophosphamide- induced myelosuppression}

The results of cyclophosphamide induced myelosuppression showed that cyclophosphamide had reduced all the haematological parameters significantly. The combined treatment of cyclophosphamide and NCM extract had increased total leukocyte count significantly from $2.5 \times 10^{3}$ counts $/ \mathrm{mm}^{3}$ (cyclophosphamide treated) to $6.4 \times 10^{3}$ counts $/ \mathrm{mm}^{3}$ (500 mg/ $\mathrm{kg}$ dose). Similarly, NCM extract had also increased the neutrophil count, lymphocyte count and haemoglobin content significantly. These results imply that NCM extract has the potential to restore the bone marrow activity prominently (Table 1).

\section{Biochemical Antioxidant assay}

The biochemical tests for the estimation of antioxidant enzymes (MDA, GSH, catalase and SOD) were carried out in both the immune organs (spleen and thymus) of myelosuppressed group and control group. The MDA level in control $(5.78 \pm 0.067 \mathrm{~nm} \mathrm{MDA} / \mathrm{mg}$ protein in spleen) was significantly reduced by cyclophosphamide treatment. These levels were further increased in NCM treated groups. GSH, catalase and SOD levels were also restored in the presence of NCM extract. Thus, the results of biochemical estimation show the capability of NCM extract to scavenge the free radicals and ROS generated due to oxidative stress (Figure 4).

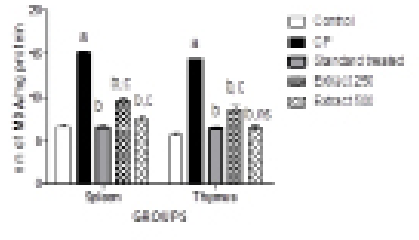

A.
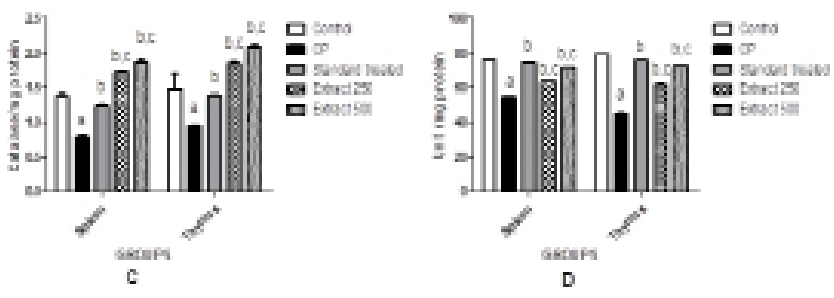

Figure 4: Effect of NCM extract on level of antioxidant status in Spleen and Thymus. A- MDA enzyme level estimation,

B- GSH enzyme level estimation, C- catalase level estimation, D- SOD unit estimation. The results are shown as the Mean \pm SD $(n=6)$ analysed by one -way ANOVA followed by Tukey's multiple comparison test. $P<0.05$ was regarded as statistically significant. a: vs. control, b: vs. CP, c: vs. Standard treated, ns is non- significant.

\section{Histopathological analysis}

The histopathological observation of spleen of control mice showed the normal structure of cortex with densely packed cortical lymphocytes (Figure 5A) while of myelosuppressed mice showed less cortical lymphocytes (Figure 5B). Due to the treatment of NCM extracts (250 mg/ $\mathrm{kg}$ and $500 \mathrm{mg} / \mathrm{kg}$ ) for 13 days, cortical lymphocytes were increased and had squeeze lymphocytes or lymph vessels along with macrophages as compared to disease control (Figure 5D and 5E). The Histological sections of thymus of myelosuppressed mice showed less lymphocytes and necrosis of lymphocytes (Figure 6B) 


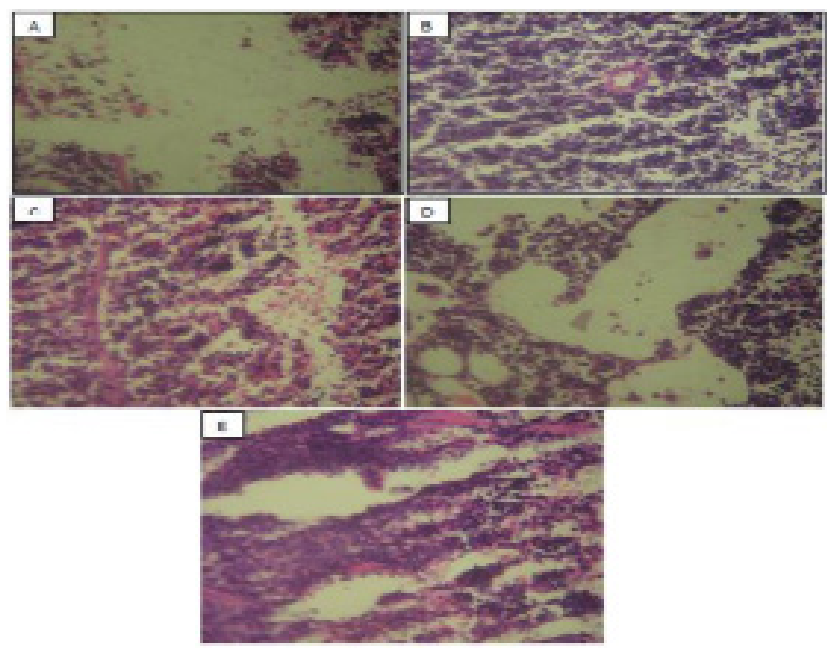

Figure 5: A-Histological sections of Spleen of control mice. B-Histological sections of Spleen of myelosuppressed mice showing less cortical lymphocytes. C-Histological sections of Spleen of standard treated group. D- Histological sections of Spleen of myelosuppressed mice treated with extract 250 $\mathrm{mg} / \mathrm{kg}$ E- Histological sections of Spleen of myelosuppressed mice treated with extract $500 \mathrm{mg} / \mathrm{kg}$.
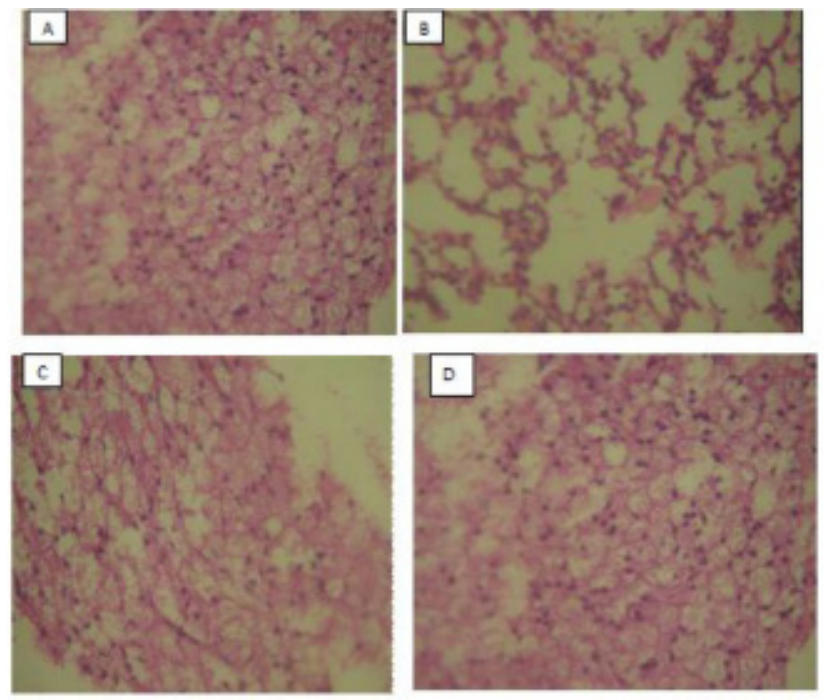

Figure 6: A- Histological sections of Thymus of control mice showing normal densely packed lymphocytes. B- Histological sections of thymus of myelosuppressed mice showing less and necrotic lymphocytes. C- Histological sections of thymus of myelosuppressed mice of standard treated group. D- Histological sections of thymus of myelosuppressed mice treated with $250 \mathrm{mg} / \mathrm{kg}$.

while NCM extract treatment $(250 \mathrm{mg} / \mathrm{kg})$ had restored the lymphocytes (Figure 6D).

\section{Effect of NCM extract on cell viability of cancer cell line}

The result of MT'T assay has been shown in Figure 7. NCM extract had decreased the \% cell viability in Jurkat J-6 cell line as compared to control. All the three

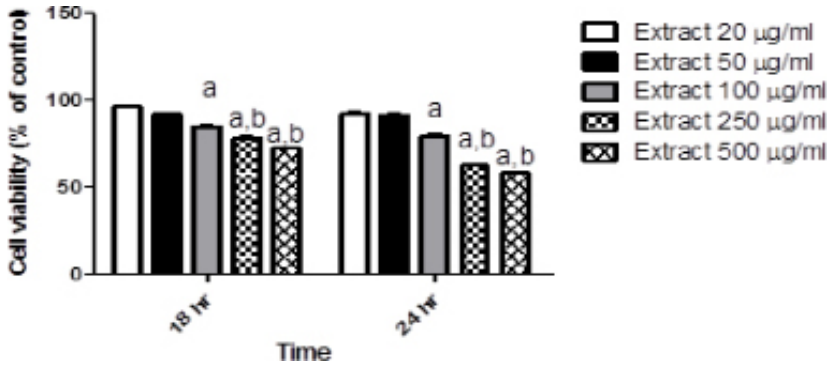

Figure 7: Cell viability count using different extract sample concentration. The results are shown as the Mean \pm SD $(n=3)$ analysed by one -way ANOVA followed by Tukey's multiple comparison test. $P<0.05$ was regarded as statistically significant. a: vs. Control, b: vs. $100 \mu \mathrm{g} / \mathrm{ml}$.

higher concentrations $(100,250$ and $500 \mu \mathrm{g} / \mathrm{ml})$ of $\mathrm{NCM}$ extract had reduced the cell viability in concentration and time dependent manner. This result indicates the anticancer potential in NCM extract.

\section{DISCUSSION}

The immune system protects the body against illness and infection, and it may help to fight against many diseases including cancer. The theory of immune surveillance suggests that the immune system is able to eliminate abnormal cells and prevent cancer formation in the body. A tumour specific adaptive immune response can potentially control tumour growth. Cancer and its treatment both weaken the immune system considerably. The plant extracts having immunomodulatory activity may be helpful for prophylactic treatment approach. ${ }^{20}$ Neolamarckia cadamba (Rubiaceae), commonly found in the temperate Himalayas and eastern parts of India, has ethnomedicinal importance in the treatment of various ailments like diabetes mellitus, diarrhoea, fever, inflammation, haemoptysis, cough, vomiting, wounds, ulcers, debility and antimicrobial activity. ${ }^{21}$ Its fruits possess antioxidant, anthelmintic, antidiabetic and membrane stabilizing properties. Still the anti-cancer activity of the fruits is not reported. Thus, in the present investigation, the immunomodulatory and anti-cancer properties of the fruits of the plant have been explored in the methanolic extract under in -vivo and in-vitro conditions.

Phytochemical screening of the methanolic extract of the fruit showed the presence of alkaloids, anthraquinone glycoside, flavonoids, phenols, tannins and terpenoids and sterol. The solvent methanol extracts polyphenol more effectively than other solvents. The fruit extract contains polyphenol rich components that may be responsible for demonstrating antioxidant activity. Phenolic compounds contain hydroxyl group that may directly contribute to antioxidant property and play a critical role in free radicals scavenging activity. Free 
radicals are harmful chemical species having one or more uncoupled electron which contributes to many diseases like AIDS, gastritis, cancer etc. ${ }^{22}$ Antioxidant activity of the extract was evaluated through DPPH assay and superoxide radical scavenging methods. In both the cases, NCM extract had shown significant free radical scavenging activity that was comparable to the standard (ascorbic acid) as well as other reported studies. $^{23}$ The results of biochemical tests for the estimation of antioxidant enzymes, (MDA, GSH, catalase and SOD) carried out in spleen and thymus of all the myelosuppressed and control group, also confirm the capability of NCM extract to scavenge the free radicals and ROS generated by oxidative stress.

Regarding immunomodulatory activity, NCM extract had significantly increased the levels of IL-2 and TNF $\alpha$ cytokines in concentration dependent manner. The immunomodulatory agents regulate the cytokine production such as, tumour necrosis factor, interleukin and interferon and these cytokines may, in turn activate $\mathrm{T}$ cells or NK cells. ${ }^{24,25}$ IL-2 promotes growth and activation of $\mathrm{T}$ lymphocytes and natural killer (NK) cells. Tumour necrosis factor (TNF) $\alpha$ is an endogenous pyrogen, is responsible for apoptotic cell death to inhibit tumorigenesis. ${ }^{26}$

Migration of neutrophils from blood stream requires a firm adhesion. $\beta 2$ integrin stored in neutrophil cells regulates this firm adherence. ${ }^{27}$ In the test for neutrophil adhesion, neutrophil index was less in nylon fibre treated blood than the untreated blood which means greater neutrophil adhesion in standard and NCM extract treated groups. The result of DTH reaction in mice, in response to cell-dependent antigen, reveals its stimulatory effect on $\mathrm{T}$ cells. It has also restored the cyclophosphamide-induced myelosuppression i.e. depletion of $\mathrm{T}$ or $\mathrm{B}$ lymphocytes, deficiency of macrophages and a significant increase in WBC count. The histopathological studies had also showed significant changes in lymphocyte, plasma cells and macrophages content. Thus, it can be concluded that this plant has significant immunomodulatory property having potent cell mediated and humoral immunomodulatory action.

Regarding anticancer activity, the cell viability determination of Jurkat J6 cell line was carried out. The results showed the increased cell death suggesting the anticancer potential of NCM extract. Thus, it may act as anticancer immunotherapeutic drug. Further, detailed investigation regarding the isolation of extract compounds and the mechanism of $N$. cadamba fruit extract for its immunotherapeutic anticancer activity is needed.

\section{CONFLICT OF INTEREST}

The authors declare no conflict of interests.

\section{ABBREVIATIONS}

NCM: Methanolic extract of Neolamarckia cadamba fruits; DTH: Delayed type hypersensitivity; SRBC: Sheep red blood cell; TNF: Tumour necrosis factor; IL-2: Interleukin-2; NK cells: Natural killer cells; ROS: Reactive oxygen species; MDA: Malondialdehyde; GSH: Glutathione; SOD: Superoxide dismutase.

\section{REFERENCES}

1. Krishnamurthi K. Screening of natural products for anticancer and antidiabetic properties. Cancer. 2007;3(4):69-75.

2. Sharma N, Kispotta S, Mazumder PM. Immunomodulatory and anticancer activity of Bombax ceiba Linn leaf extract. Asian Pac J Trop Biomed. 2020;10(9):426-32.

3. Pandey A, Negi PS. Traditional uses, phytochemistry and pharmacological properties of Neolamarckia cadamba: A review. J Ethnopharmacol. 2016;181:118-35.

4. Dwevedi A, Sharma K, Sharma YK. Cadamba: A miraculous tree having enormous pharmacological implications. Pharmacog Rev. 2015;9(18):107-13.

5. Chandel M, Kumar M, Sharma U, Singh B, Kaur S. Investigations on Antioxidant, Antiproliferative and COX-2 Inhibitory Potential of Alkaloids from Anthocephalus cadamba (Roxb.) Miq. Leaves. Chem Biodivers. 2017;14(4):e1600376.

6. Singh S, Ishar MPS, Saxena A, Kaur A. Cytotoxic effect of Anthocephalus cadamba Miq. leaves on human cancer cell lines. Pharmacog J. 2013;5(3):127-9.

7. Khandelwal V, Bhatia AK, Goel A, Choudhary P, Goel R. Studies of Anthocephalus cadamba leaf extract on haematological and biochemical parameters of albino rats. J Chem Pharm Res. 2015;7(6):765-71.

8. Islam T, Das A, Shill KB, Karmakar P, Islam S, Sattar MM. Evaluation of membrane stabilizing, anthelmintic, antioxidant activity with phytochemical screening of methanolic extract of Neolamarckia cadamba fruits. J Med Plants Res. 2015;9(5):151-8.

9. Sanadhya I, Durve A. Isolation and characterisation of antimicrobial compound from fruits of Anthocephalus indicus A. Rich. Int J Pharm Pharm Sci. 2014;6:285-91.

10. Onyebuchi C, Kavaz D. Chitosan and N, N, N-Trimethyl Chitosan Nanoparticle Encapsulation of Ocimum gratissimum Essential Oil: Optimised Synthesis, in vitro Release and Bioactivity. Int J Nanome. 2019;14:7707-27.

11. Kavaz D, Idris M, Onyebuchi C. Physiochemical characterization, antioxidative, anticancer cells proliferation and food pathogens antibacterial activity of chitosan nanoparticles loaded with Cyperus articulatus rhizome essential oils. Int J Biol Macromol. 2019;123:837-45.

12. Zargar BA, Masoodi MH, Ahmed B, Ganie SA. Antihyperlipidemic and antioxidant potential of Paeonia emodi Royle against high-fat diet induced oxidative stress. ISRN Pharmacol. 2014;10:201-4.

13. Sharma N, Banerjee S, Mazumder PM. Evaluation of the mechanism of anticancer activity of deltamethrin in Jurkat-J6 cell line. Pesticide Biochem Physiol. 2018;149:98-103.

14. Nfambi J, Bbosa GS, Sembajwe LF, Gakunga J, Kasolo JN. Immunomodulatory activity of methanolic leaf extract of Moringa oleifera in Wistar albino rats. J Basic Clin Physiol Pharmacol. 2015;26(6):603-11.

15. Han J, Xia J, Zhang L, Cai E, Liu S. Studies of the effects and mechanisms of ginsenoside Re and Rk3 on myelosuppression induced by cyclophosphamide. J Ginseng Res. 2019;43(4):618-24.

16. Nagarathna PKM, Reena K, Reddy S, Wesley J. Evaluation of immunomodulatory activity of the flavanoid of Kigelia africana. Int J Pharm Sci Res. 2014;5(10):4359-65. 
17. Artym J, Kochanowska IE, Kocięba M, Zaczyńska E, Pluta K. Selected azaphenothiazines inhibit delayed type hypersensitivity and carrageenan reaction in mice. Int Immunopharmacol. 2016;40:265-8.

18. Ibrahim K, Al-Mutary M, Bakhiet A, Khan H. Histopathology of the liver, kidney and spleen of mice exposed to gold nanoparticles. Molecules. 2018;23(8):1848.

19. Pathak N, Khandelwal S. Immunomodulatory role of Piperine in Cadmium induced thymic atrophy and splenomegaly in mice. Environ Toxicol Pharmacol. 2009;28(1):52-60.

20. Miller KD, Siegel RL, Lin CC, Mariotto AB, Kramer JL, Rowland JH, et al. Cancer treatment and survivorship statistics. CA: A Cancer Journal for Clinicians. 2016;66(4):271-89.

21. Bala M, Kumar M, Chandel M, Sharma N, Kaur S, Kaur SJ. Antioxidant, antimutagenic and cytotoxic effects of unripe fruits of Anthocephalus cadamba (Roxb.) Miq. Ind Drugs. 2017;54:7-15.

22. Muniyandi K, George E, Sathyanarayanan S, George BP, Abrahamse H, Thamburaj S, et al. Phenolics, tannins, flavonoids and anthocyanins contents influenced antioxidant and anticancer activities of Rubus fruits from Western Ghats, India. Food Sci Human Wellness. 2019;8(1):73-81.

23. Kumar RP, Venkatesh S, Reddy MB. Immunomodulatory and Antioxidant Activity of Chloroform Extract of Ficus racemosa Linn. Stem Bark. Indian J Pharm Educ Res. 2013;1;47(2):178-82.

24. Pandey RK, Shukla SS, Jain A, Gupta VB, Deb L. Evaluation of comparative immunomodulatory potential of Solanum xanthocarpum root and fruits on experimental animal. Indian J Pharm Educ Res. 2018;1;52(4 Suppl 2):237-45.

25. Abdoon IH, Parveen B, Bashier OMS, Osman WJ, Ahmad S. Immunomodulatory Potential of Leptadenia arborea in Immune-Challenged Rats. Indian J Pharm Educ Res. 2020;54(1):101-7.

26. Yamanaka R, Hayano A, Kanayama T. Radiation-induced meningiomas: An exhaustive review of the literature. World Neurosurgery. 2017;97:635-44

27. Yona S, Gordon S. From the reticuloendothelial to mononuclear phagocyte system-The unaccounted years. Front Immunol. 2015;6:328-53.

Cite this article: Chatterjee A, Sharma N, Mazumder PM. Evaluation of Antioxidant, Immunomodulatory and Anticancer Properties of Methanolic Extract of Neolamarckia cadamba Linn. Fruits. Indian J of Pharmaceutical Education and Research. 2021;55(2s):s501-s509. 